JPP IPTEK Mei 2019, Vol. 3, No. 1

ISSN 2620-7745 (online)

https://dx.doi.org/10.31284/j.jpp-iptek.2019.v3i1.473

\title{
Strategi Pengenalan Membaca Phonics Method dalam Pengabdian kepada Masyarakat di Jakarta Selatan
}

\author{
Ayu Bandu Retnomurti ${ }^{1}$, Nurmala Hendrawaty ${ }^{2}$, Nurhayati ${ }^{3}$ \\ 1,2,3 Pendidikan Bahasa Inggris, Universitas Indraprasta PGRI Jakarta \\ 12ayubandu@gmail.com, ${ }^{2}$ malahendrawaty@yahoo.com, ${ }^{3}$ nuansa_bunda@yahoo.com
}

\begin{abstract}
The purposes of this community service are to recognize the strategy of reading English vocabulary through Phonics method for teachers and to explain the output product produced by the Phonics method. The community service was conducted in Jagakarsa area of South Jakarta in odd semester 2018/2019. Phonics method is one of the methods of reading namely "Teachers teach students how to sound the letters and mix sounds together to form words, and Phonics method is a technique of learning reading that emphasizes sound (Pronunciation) produced by letters contained in the word (such sounds can be different from the name of these letters; for example, in English the sound of the letter c [si] is not in accordance with the pronunciation of the word [cat]. The strength of this method is the students are easy to make connections between words and sounds. Besides, they can sound and read it themselves. Learning English using Phonics instruction is much more effective than learning reading without it. On the basis of consideration, it is suggested that the teachers are able to use an appropriate method or interesting learning strategy to make students feel enthusiastic in learning. In addition, they are able to create a comfortable and pleasant classroom atmosphere. Last but not least, it is expected that there are two or more teachers in the classroom to speak appropriately and loudly when Phonics is sounded so that the students are able to hear clearly.
\end{abstract}

Keywords: Reading strategy, Phonics method, Teachers

\section{ABSTRAK}

Tujuan dilaksanakannya pengabdian masyarakat ini yaitu untuk menjelaskan bagaimana strategi pengenalan membaca kosakata bahasa Inggris melalui metode phonics bagi Guru di wilayah Jagakarsa Jakarta Selatan semester Gasal 2018/2019 dan menjelaskan produk luaran yang dihasilkan melalui strategi phonics dalam kegiatan pengabdian masyarakat ini. Metode phonics merupakan salah satu metode membaca yakni "Para guru mengajarkan siswa bagaimana bunyi-bunyi huruf itu maupun mencampur bunyi-bunyi secara bersama-sama untuk membentuk kata dan metode bunyi (phonics method) merupakan suatu teknik belajar membaca yang menekankan pada bunyi (lafal pengucapan) yang dihasilkan oleh huruf-huruf yang terdapat di dalam kata (bunyi semacam itu dapat berbeda dari nama-nama huruf ini, seperti dalam bahasa Inggris ketika bunyi huruf c [si] tidak sesuai dengan pengucapan kata [cat]." Selain itu, kelebihan metode ini adalah memudahkan siswa membuat hubungan otomatis antara kata dan bunyi, siswa dapat membunyikan dan membacanya sendiri. Pembelajaran bahasa Inggris menggunakan instruksi phonics lebih efektif daripada belajar membaca tanpa instruksi phonics. Mengacu pada hal tersebut disarankan bahwa bagi sekolah diharapkan mampu mengarahkan guru untuk menggunakan metode atau strategi pembelajaran yang mempu menarik antusias siswa dalam belajar serta menciptakan suasana kelas yang nyaman dan menyenangkan. Bagi guru, ketika pembelajaran berlangsung diharapkan ada dua orang guru atau lebih untuk mengondisikan serta diharapkan guru berbicara secara tepat dan lantang ketika pembunyian huruf phonics sehingga siswa mampu mendengar dengan jelas.

Kata kunci: Strategi membaca, Metode bunyi, Guru

\section{PENDAHULUAN}

Bahasa merupakan suatu sistem simbol yang mengantegorikan, mengorganisasi, dan mengklarifikasi pikiran kita. Bahasa pada anak-anak usia lima tahun berkembang secara terus menerus, dan perbendaharaan kata-kata mereka meluas sampai 5.000 ke 8.000 kata. Menurut Colla (2001) tentang Pendidikan Sekolah disebutkan bahwa aspek bahasa siswa meliputi memahami bahasa reseptif (menyimak dan membaca), memahami bahasa ekspresif (mengungkapkan bahasa secara verbal dan non-verbal), dan mengenal keaksaraan melalui bermain yang terdiri atas: a) memahami bahasa reseptif, mencakup kemampuan memahami cerita, perintah, aturan, 
menyenangi dan menghargai bacaan; b) mengekspresikan bahasa, mencakup kemampuan bertanya, menjawab pertanyaan, berkomunikasi secara lisan, menceritakan kembali yang diketahui, belajar bahasa pragmatik, mengekspresikan perasaan, ide, dan keinginan dalam bentuk coretan; dan c) Keaksaraan, mencakup pemahaman terhadap hubungan bentuk dan bunyi huruf, meniru bentuk huruf, serta memahami kata dalam cerita.

Salah satu cara untuk mengembangkan kemampuan berbahasa adalah melalui membaca. Studi menunjukkan bahwa anak-anak muda dapat belajar membaca dari usia empat tahun. Siqueira, Cortez, Kelly, Sobrinho \& Rocha (2016) menyatakan bahwa salah satu keterampilan paling penting anak ketika mulai sekolah yaitu dengan memulai belajar membaca. Anak usia TK telah memiliki dasar kemampuan untuk belajar membaca dan menulis. Anak mulai menyadari bahwa kata merupakan ungkapan dari simbol-simbol grafik yang mengandung arti. Selanjutnya, ia mulai memusatkan perhatiannya pada satu atau dua aspek dari suatu kata, seperti huruf pertama yang ada dalam satu kata dan gambarnya juga mengemukakan bahwa anak yang sudah memiliki kesiapan membaca di TK akan lebih percaya diri dan penuh kegembiraan. Attwell (2007) menyatakan bahwa membaca permulaan dan kemampuan menulis bagi anak usia dini dan anak TK merupakan sesuatu hal yang penting dan menjadi awal yang kuat untuk kemampuan keaksaraan dan prestasi di sekolah menyelidiki hubungan antara keterampilan keaksaraan muncul di periode prasekolah dan kemampuan membaca pada usia sekolah mengidentifikasi keterampilan abjad sebagai predictor yang kuat bahwa instruksi membaca awal, akan mempengaruhi strategi yang mereka gunakan untuk mengenali kata-kata.

Metode phonics adalah suatu cara mengajarkan baca tulis dengan mengajarkan bunyi hurufhuruf secara multisensori, kemudian menggunakan cara sintesa bunyi untuk membaca kata (Mishra \& Koehler, 2006). Sejalan dengan pendapat tersebut, Cologon, Cupples \& Wyver (2011) menyatakan bahwa instruksi phonics melibatkan memeriksa setiap kata secara individual sebagai suara individu dan kemudian mencampurkan suara secara bersama-sama.

Phonics Method merupakan salah satu metode membaca yaitu "Para guru mengajarkan anak- anak bagaimana bunyi-bunyi huruf itu maupun mencampur bunyi-bunyi secara bersamasama untuk membentuk kata" (Lana-Peixoto \& Teixeira, 2002). Pendapat tersebut sejalan dengan pernyataan Gates \& Yale (2011) yang mengemukakan, "Metode bunyi (phonics method) merupakan suatu teknik belajar membaca yang menekankan pada bunyi (lafal pengucapan) yang dihasilkan oleh huruf-huruf yang terdapat di dalam kata (bunyi semacam itu dapat berbeda dari nama-nama huruf ini, seperti dalam bahasa Inggris ketika bunyi huruf c [si] tidak sesuai dengan pengucapan kata [cat]."

Menurut Fridani (2014), phonics merupakan salah satu metode untuk anak yang lebih besar (sudah mengenal huruf) yang merasakan sukar membaca. Selain itu, kelebihan metode ini adalah memudahkan anak membuat hubungan otomatis antara kata \& bunyi, anak dapat membunyikan dan membacanya sendiri (Hendriansyah et al., 2013). Pembelajaran Bahasa Inggris menggunakan instruksi phonics lebih efektif daripada belajar membaca tanpa instruksi phonics (Connelly, 2002).

Ada dua macam phonics method, yaitu analytic phonics dan synthetic phonics. Menurut Jung, Baynes \& Beebe (2016), analytic phonics dimulai dengan anak menganalisis suara dalam kata-kata yaitu mereka mulai dengan kata dan mengambilnya terpisah misalnya, kata cinta yang diajarkan pertama kali kemudian mengatakan empat suara c/ i / n / t / a. Kemudian setelah itu anak mengatakan setiap suara, mereka berbaur dengan tiga suara bersama-sama. Sedangkan Wyse \& Goswami (2008) menyatakan bahwa synthetic phonics diajarkan kepada anak setelah beberapa huruf dan bunyi huruf, kemudian mereka menunjukkan bagaimana bunyi dapat dicampur bersama membentuk sebuah kata. Lebih lanjut mereka menyatakan bahwa pendekatan fonik sintetis dimulai pada saat pelajar mengeluarkan suara dan mencampurkan huruf untuk membentuk kata-kata. Beberapa contoh s-e-k-o-l-a kemudian sekola (sekolah), dari bagian ke seluruh.

Dalam kegiatan pengabdian masyarakat ini, tim pelaksana menggunakan pendekatan shynthetic phonics. Pendekatan tersebut dipilih karena dianggap paling cocok untuk digunakan dalam pengenalan membaca pada anak-anak SMP. Hal ini diperkuat oleh Wyse \& Goswami (2008) yang menyatakan bahwa pada anak usia sekolah menengah pertama dan atas, pembelajarannya memfokuskan pada synthetic phonics, yaitu kata dipisah menjadi bagian terkecil dari unit yaitu 
suara (fonem). Anak-anak diajari huruf (graphemes) dan merepresentasikan ke dalam fonem dan juga belajar mencampurnya kedalam kata. Hal ini menunjukkan bahwa phonics sintetik sistematis instruksi lebih baik dari instruksi phonics analitik dalam mengembangkan kesadaran fonemik, kata membaca, mengeja dan pemahaman bacaan (Mulyana, 2008).

Phonics bukanlah metode mengajar membaca, tetapi merupakan bagian penting dari setiap metode dan modern. Ini adalah kunci untuk penguasaan kata, dan penguasaan kata adalah salah satu hal penting pertama dalam belajar membaca. Sebuah pengetahuan tentang suara huruf, dan efek dari posisi surat suara pada perusahaan, merupakan sarana penting menguasai mekanisme membaca, dan memungkinkan siswa untuk menjadi pembaca mandiri.

Metode pengajaran apa yang terbaik untuk mengajarkan siswa bagaimana membaca: apakah phonics atau metode seluruh bahasa yang lebih baik. Metode seluruh bahasa menjadi metode yang disukai dari sistem pendidikan- sayangnya seluruh bahasa belajar membaca metode yang lebih dari rencana "kata menghafal", yaitu seorang anak muda seharusnya menghafal "bentuk" kata, dan mempelajarinya. Sejak itu, ribuan studi, memiliki phonics terbukti dan kesadaran fonemik menjadi keunggulan dalam mengajar siswa untuk membaca dan menulis, ketika Panel Membaca Nasional menyatakan bahwa pengajaran phonics dan kesadaran fonemik menghasilkan hasil yang lebih baik daripada program membaca seluruh bahasa setelah penelitian mereka yang terakhir dan mengidentifikasi 1.962 studi tentang subjek ini.

Hal yang penting untuk membedakan perbedaan antara kesadaran fonologi dan kesadaran fonemik. Kesadaran fonologi sangat luas dan termasuk kesadaran fonemik sebagai sub kategori. Kesadaran fonemik sangat sempit dan hanya terfokus pada fonem yang merupakan suara individu huruf. Tidak ada kekurangan penelitian yang telah berulang kali menemukan, dan menyimpulkan bahwa mengajar kesadaran fonemik untuk anak-anak menghasilkan bacaan yang luar biasa dan kemampuan ejaan. Kita dapat membaca lebih lanjut tentang penelitian tentang kesadaran fonemik ini.

Metode bahasa hanya mengharapkan anak untuk "membaca" ketika disajikan bahan bacaan, dan dengan menghafal kata-kata pandangan. Metode phonics adalah atas dasar pendekatan yakni guru mengajar siswanya untuk membaca dalam urutan logis dan berurutan. Guru pertama kali mengajarkan anak huruf alfabet dan suara mereka mewakili, maka guru mengajar siswa untuk menggabungkan (atau campuran) huruf berbagai suara bersama-sama untuk membentuk kata, yang kemudian diikuti dengan membaca kalimat dan cerita yang sederhana. Ini adalah perkembangan yang logis untuk siswa belajar membaca, yakni mereka mengembangkan akurasi dalam kata-kata dan mengucapkan kata kata. Metode pengajaran juga membantu siswa untuk mengeja dengan benar. Tidak ada keraguan bahwa phonics instruksi dan kesadaran fonemik adalah metode unggul untuk mengajar anak-anak cara membaca.

Salah satu metode pembelajaran membaca yang saat ini diterapkan di SMP PATTIMURA wilayah Jagakarsa Jakarta Selatan yaitu dengan metode komunikatif dan metode ceramah. Dalam penerapan metode tersebut, anak mengikuti perintah dari guru dengan mengerjakan tugas di lembar kerja anak, guru menyuruh anak menulis dan membaca kata di papan tulis, serta anak juga rutin diminta untuk membaca melalui buku baca anak. Ketika pembelajaran seperti ini dilakukan berulang-ulang dan menjadi kebiasaan maka akan menimbulkan tekanan dan kejenuhan karena anak masih dalam dunia belajar.

Berdasarkan dari analisis situasi yang telah diuraikan, tim pelaksana tertarik untuk mengadakan kegiatan ABDIMAS untuk menjelaskan strategi phonics method bagi guru di wilayah Jagakarsa Jakarta Selatan menggunakan pola ejaan bahasa Indonesia. Oleh karena itu, tim pelaksana ABDIMAS ingin mengadakan kegiatan dengan judul "Strategi Pengenalan Membaca melalui Metode Phonics Bahasa Inggris Guru di wilayah Jagakarsa Jakarta Selatan"

Kurikulum yang digunakan dewasa ini berorientasi pada kompetensi, artinya siswa dituntut untuk memiliki kompetensi tertentu atau kecakapan sebagai hasil proses pembelajaran di sekolah. Pendidikan berbasis kompetensi menekankan pada kemampuan yang harus dimiliki oleh lulusan suatu jenjang pendidikan. Kompetensi yang sering disebut dengan standar kompetensi adalah kemampuan yang secara umum harus dikuasai lulusan. Kompetensi adalah "pernyataan yang menggambarkan penampilan suatu kemampuan tertentu secara bulat yang merupakan perpaduan antara pengetahuan dan kemampuan yang dapat diamati dan diukur". Kompetensi (kemampuan) 
lulusan merupakan modal utama untuk bersaing di tingkat global, karena persaingan yang terjadi adalah pada kemampuan sumber daya manusia. Oleh karena. itu, penerapan pendidikan berbasis kompetensi diharapkan akan menghasilkan lulusan yang mampu berkompetisi di tingkat global.

Dalam pelaksanaan proses pembelajaran bahasa Inggris, tim pelaksana mengamati para guru di SMP PATTIMURA Jagakarsa Jakarta Selatan mengalami kesulitan dalam mencapai suatu kompetensi dasar. Hal ini dikarenakan penguasaan membaca kosakata bahasa Inggris kurang memadai, sehingga sangat mengganggu pencapaian kompetensi seperti yang tertera dalam kurikulum. Mereka sering kesulitan memahami pengucapan sebuah kata karena pemahaman membaca kosakata mereka relatif kurang memadai sehingga proses pencapaian suatu kompetensi dasar akan berjalan lebih lama. Apabila para siswa mengalami kesulitan dalam melafalkan sebuah kata selama proses pembelajaran, maka solusi akhirnya yaitu memberikan jalan pintas pada mereka dengan cara meminta siswa melafalkan kata tersebut dalam kamus atau berbagai sumber, memberitahu secara langsung pelafalan kata tersebut. Walaupun cara tersebut jika terlalu sering digunakan berakibat kurang baik bagi para siswa karena hanya beberapa orang siswa yang mau mencari sumber belajar lain, siswa menjadi tergantung pada sumber itu bukan pada pemahaman konteks pengucapan kata, dan siswa sering menunggu bagaimana cara melafalkan kata dari guru.

Berdasarkan alasan di atas, perumusan masalah dari kegiatan pelatihan ABDIMAS ini yaitu: Bagaimanakah strategi pengenalan membaca kosakata Bahasa Inggris melalui metode Phonic bagi guru SMP PATTIMURA Jagakarsa Jakarta Selatan? Dan Apakah produk luaran yang dihasilkan melalui strategi Phonics dalam kegiatan pengabdian masyarakat ini?

Melihat kendala-kendala di atas, maka tim pelaksana ABDIMAS mencoba mencari strategi pengenalan membaca atau melafalkan kosakata Bahasa Inggris bagi guru SMP PATTIMURA Jagakarsa Jakarta Selatan, dengan harapan para guru dan siswa nanti tidak selalu bergantung pada sumber belajar manapun dalam melafalkan sebuah kata, sehingga hal ini diharapkan akan memudahkan pencapaian suatu kompetensi berbahasa sekaligus meningkatkan pemahaman siswa akan pelafalan kosakata Bahasa Inggris.

\section{METODE PELAKSANAAN}

Data yang digunakan dalam kegiatan pengabdian masyarakat ini merupakan hasil pengamatan di kelasdan studi pustaka.

Dalam pelaksanaan pengabdian masyarakat ini digunakan:

\subsection{Tahap Persiapan}

Tahap persiapan meliputi identifikasi kebutuhan, perijinan, dan pengadaan media pembelajaran, metode pengumpulan data menggunakan observasi, wawancara dan dokumentasi.

1) Identifikasi kebutuhan. Dalam tahap ini dilakukan identifikasi untuk mendapatkan gambaran tentang kondisi sekolah serta kebutuhan pembelajaran bahasa Inggris.

2) Perijinan. Dalam tahap ini dilakukan permohonan ijin dari pihak sekolah SMP PATTIMURA di wilayah Jagakarsa Jakarta Selatan

3) Pengadaan media pembelajaran pelafalan kosakata. Media yang digunakan adalah media audio-visual pelafalan anak-anak berbahasa Inggris.

\subsection{Tahap Pelaksanaan}

Pelaksanaan pelatihan kosakata berbahasa Inggris melalui strategi membaca Phonics atau metode bunyi-bunyian berbahasa Inggris dilaksanakan sebanyak empat kali pelatihan dari AgustusDesember 2018 dengan jumlah peserta 15 guru dari SMP dengan mengikutsertakan beberapa guru pengajar, sehingga dalam tindak lanjut pembelajaran, guru pengampu dapat melanjutkan metode Phonics ini dalam pembelajaran kelas sehari-hari.

Pelatihan bagi guru SMP \& SMA PATTIMURA non mata pelajaran Bahasa Inggris dilakukan dalam empat kali pertemuan $(1 \times 2$ jam $)$. Pelatihan dilakukan sesudah jam sekolah agar tidak mengganggu jalannya proses belajar mengajar. 
Tabel 1. Daftar Nama Peserta Pelatihan

\begin{tabular}{rll}
\hline No. & Nama & Keterangan \\
\hline 1 & Saniah, M.Pd. & Kepsek SMP Pattimura \\
2 & Desy Sri Andayawry, S.Pd. & Wakepsek SMP Pattimura \\
3 & Tri Indriyani, S.Pd. & Guru SMP \\
4 & Ruspita Sari, S.Pd. & Guru SMP \\
5 & Lina Rosiana, S.Pd. & Guru SMP \\
6 & Achmad Sofyan, S.Pd. & Guru SMP \\
7 & Rini Budiati, S.Pd. & Guru SMP \\
8 & Ismail, S.Pd. & Guru SMP \\
9 & Juni Rachmat, S.Pd. & Guru SMP \\
10 & Gunarto, S.Pd. & Guru SMP \\
11 & Dwi Wibowo S., S.Pd. & Guru SMP \\
12 & Nurdin, S.Pd. & Guru SMP \\
13 & Fakri, S.Pd. & Guru SMP \\
14 & Ahmad Nur, S.Pd. & Guru SMP \\
15 & Siti Khasanah, S.Pd. & Guru SMP \\
\hline
\end{tabular}

\section{HASIL DAN PEMBAHASAN}

Pelatihan dilaksanakan pada bulan Agustus-Desember 2018. Hasil dalam pelatihan ini terdiri dari tiga sub yang meliputi bentuk dan penerapan kegiatan pembelajaran melalui strategi phonic method, kemampuan anak untuk mengenali kata saat membaca dipengaruhi oleh cara pengajaran atau metode mengajar yang digunakan oleh guru. Phonics adalah jalan untuk mengkode atau menghubungkan huruf yang tertulis dan pelafalan suara. Instruksi phonics mengajarkan anak bahwa adanya hubungan antara huruf dari bahasa tertulis dan suara individu (bunyi) dari bahasa lisan. Metode phonics adalah suatu cara mengajarkan baca tulis dengan mengajarkan bunyi hurufhuruf secara multisensori, kemudian menggunakan cara sintesa bunyi untuk membaca kata. Dengan kata lain, instruksi phonics melibatkan memeriksa setiap kata secara individual sebagai suara individu dan kemudian mencampurkan suara secara bersama-sama. Phonics Method merupakan salah satu metode membaca yakni "Para guru mengajarkan anak- anak bagaimana bunyi-bunyi huruf itu maupun mencampur bunyi-bunyi secara bersama-sama untuk membentuk kata". Lebih lanjut, "Metode bunyi (phonics method) merupakan suatu teknik belajar membaca yang menekankan pada bunyi (lafal pengucapan) yang dihasilkan oleh huruf-huruf yang terdapat di dalam kata (bunyi semacam itu dapat berbeda dari nama-nama huruf ini, seperti dalam bahasa Inggris ketika bunyi huruf c [si] tidak sesuai dengan pengucapan kata [cat]". Ada dua macam phonics method, yaitu analytic phonics dan synthetic phonics. Analytic phonics dimulai dengan anak menganalisis suara dalam kata-kata yaitu mereka mulai dengan kata dan mengambilnya terpisah misalnya, kata cinta yang diajarkan pertama kali kemudian mengatakan empat suara $\mathrm{c} / \mathrm{i} / \mathrm{n}$ / t / a. Kemudian setelah itu anak mengatakan setiap suara, mereka berbaur dengan tiga suara bersama-sama. Sementara, synthetic phonics diajarkan kepada anak setelah beberapa huruf dan bunyi huruf, kemudian mereka menunjukkan bagaimana bunyi dapat dicampur bersama membentuk sebuah kata. Pendekatan fonik sintetis dimulai di mana pelajar mengeluarkan suara dan mencampurkan huruf untuk membentuk kata-kata. Beberapa contoh s-e-k-o-l-o kemudian sekolo (sekolah), dari bagian keseluruhan.

Kegiatan pembelajaran melalui penggunaan strategi Phonic method di SMP PATTIMURA Jagakarsa menggunakan kumpulan video Phonics Song with two words-A for Apple-ABC for Alphabet songs with sounds for children. Beberapa tahapan pembelajaran yang dapat teramati antara lain sebagai berikut:

a. Guru menayangkan video dari Phonics song with two words-A for Apple-ABC for Alphabet songs with sounds for children yang memiliki pola irama dan lirik pada siswa. 
b. Siswa mengikuti gerakan suara \& pelafalannya yang ada dalam tayangan dan dikenalkan konsep pola secara tidak langsung melalui tayangan tersebut.

c. Setelah tayangan selesai, guru menanyakan bagaimana cara pengucapan yang ada dalam video tersebut.

Berikut contoh kegiatan pembelajaran melalui strategi phonics method di SMP Pattimura yang dilakukan oleh tim pelaksana ABDIMAS, adalah sebagai berikut:

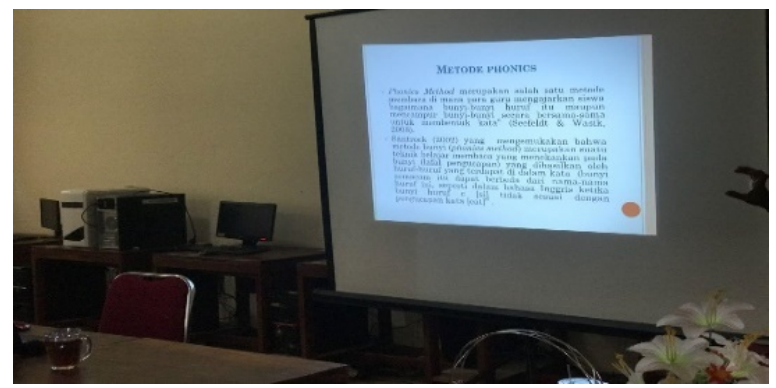

Gambar 1. Dokumentasi Kegiatan Pelatihan ABDIMAS

Dalam kegiatan pengabdian masyarakat ini, tim abdimas menggunakan pendekatan shynthetic phonics. Pendekatan tersebut dipilih karena dianggap paling cocok untuk digunakan dalam pengenalan membaca pada siswa, karena pembelajarannya memfokuskan pada synthetic phonics, yaitu kata dipisah menjadi bagian terkecil dari unit yaitu suara (fonem). Siswasiswi diajari huruf (graphemes) dan merepresentasikan ke dalam fonem dan juga belajar mencampurnya kedalam kata. Oleh karena itu, phonics sintetik sistematis instruksi lebih baik dari instruksi phonics analitik dalam mengembangkan kesadaran fonemik, kata membaca, mengeja dan pemahaman bacaan.

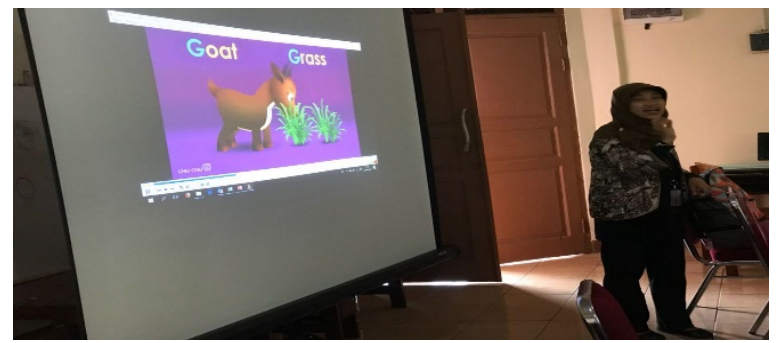

Gambar 2. Dokumentasi saat tim pelaksana menyajikan materi Phonics method

Hasil wawancara yang telah dilakukan dengan guru setelah perlakuan menggunakan phonics method menunjukkan bahwa anak menjadi lebih memahami tentang huruf-huruf dan lebih mudah mengaitkan hubungan bunyi dengan katanya. Phonics method memudahkan anak membuat hubungan otomatis antara kata \& bunyi, anak dapat membunyikan dan membacanya sendiri. Pada saat treatment berlangsung, anak mampu mengaitkan antara bunyi huruf yang satu dengan yang lain sehingga mampu membentuk sebuah suku kata dan kata.Penggunaan phonics method dapat menjadikan sebagian anak yang sukar membaca menjadi lebih fasih membaca. Salah satu metode untuk anak yang lebih besar (sudah mengenal huruf) yang merasakan sukar membaca.

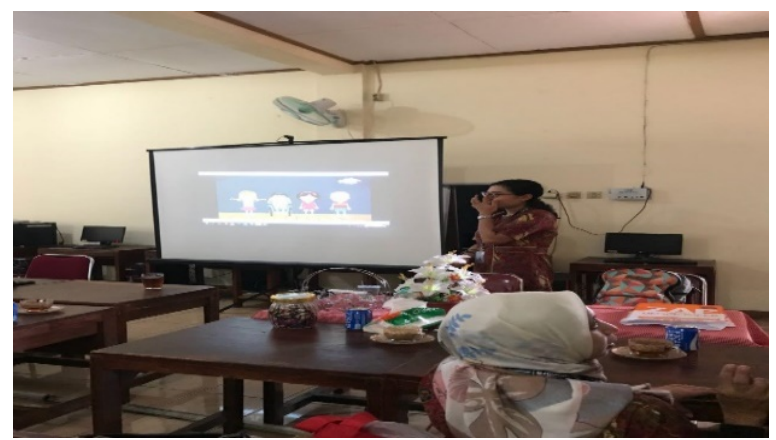

Gambar 3. Dokumentasi saat tim pelaksana memutar video pelafalan bunyi \& huruf dalam Phonics Method 
Penggunaan phonics method terhadap kemampuan membaca permulaan menunjukkan bahwa siswa sangat antusias dalam merespon metode ini, dikarenakan metode ini menggunakan bantuan lagu dan games. "Nyanyian, rima, pembacaan puisi, dan permainan kata merupakan sumber permainan yang menyenangkan dan akan meningkatkan kesadaran siswa mengenai pola bunyi dan perbedaan bunyi pada siswa". Pada saat penerapan phonics method di kelas, mereka terlihat tertarik dan semangat ketika Ibu Guru memberikan nyanyian tentang bunyi huruf, kartu gambar serta permainan-permainan yang berpengaruh pada peningkatan pemahaman mengenai bunyi-bunyi huruf dan bentuk hurufnya.

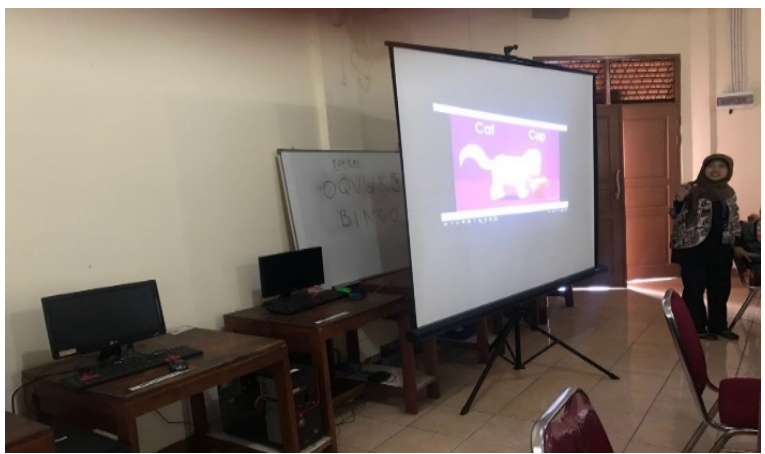

Gambar 4. Dokumentasi saat tim pelaksana melafalkan setiap bunyi \& huruf dalam Phonics Method

Salah satu metode pembelajaran membaca yang saat ini diterapkan di SMP PATTIMURA yaitu dengan metode komunikatif dan metode ceramah. Dalam penerapan metode tersebut, siswasiswi mengikuti perintah dari guru dengan mengerjakan tugas di lembar kerja siswa, guru menyuruh siswa menulis dan membaca kata di papan tulis, serta siswa juga rutin diminta untuk membaca melalui buku bacan siswa. Ketika pembelajaran seperti ini dilakukan berulang-ulang dan menjadi kebiasaan, maka akan menimbulkan tekanan dan kejenuhan karena siswa masih dalam penyesuaian dengan phonic method yang masih awam diserapnya.

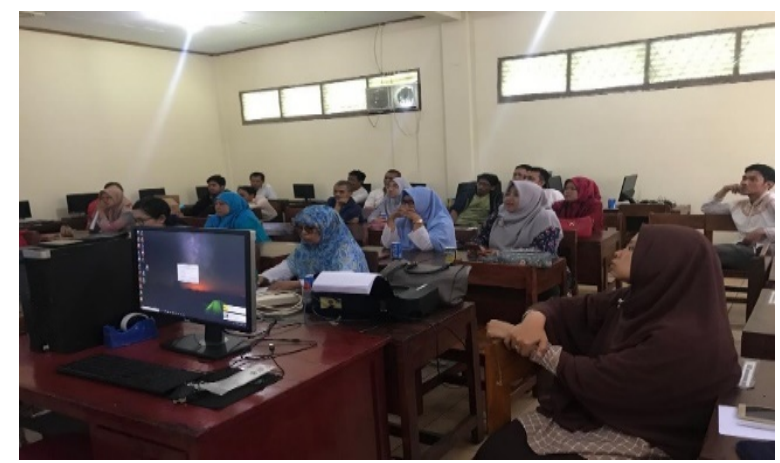

Gambar 5. Dokumentasi suasana pelatihan PKM Guru di SMP PATTIMURA Jagakarsa Jakarta Selatan

Setelah dilakukan pelatihan, pembelajaran membaca pada kelompok siswa SMP PATTIMURA menjadi lebih aktif dan menyenangkan serta mereka lebih cepat dalam menguasai. Hal itu diungkapkan bahwa phonics method efektif untuk mengajarkan siswa membaca (dengan pola ejaan atau lafal bahasa Inggris) secara aktif dan menyenangkan sehingga mereka cepat menguasai. Kenyataannya di lapangan, phonics method tidak hanya efektif mengajarkan membaca secara menyenangkan menggunakan pola atau lafal bahasa Inggris, namun juga mampu membuat pembelajaran membaca dengan pola Bahasa Indonesia menjadi lebih menyenangkan dan mengasyikkan. 


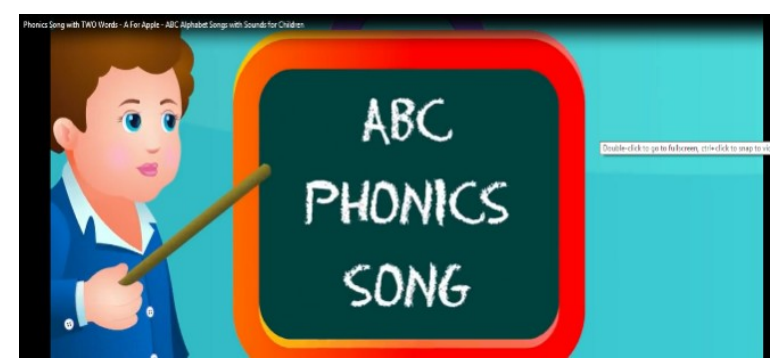

Gambar 6. Video Pelafalan phonic method "ABC Phonics Song"

Berdasarkan hasil yang ditunjukkan, penggunaan phonics method mampu memberikan pengaruh terhadap adanya peningkatan kemampuan membaca. Terbukti ketika siswa mampu membaca suku kata berpola vokal konsonan dan konsonan vokal, serta mampu membaca kata dengan lebih lancar. Namun, satu orang siswa mengalami penurunan kemampuan membaca permulaan. Siswa menjadi kurang percaya diri dan masih bingung ketika diminta untuk membaca suku kata, khususnya yang berpola vokal konsonan dan membaca kata utuh.

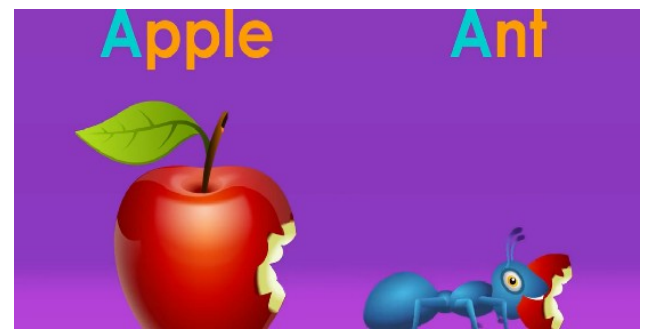

\section{Gambar 7.Contoh Huruf Fonem dalam Phonics Method}

Kemampuan bercerita siswa mengalami penurunan pada anak setelah diberikan perlakuan phonics method yang dipengaruhi oleh dua faktor. Pertama, siswa tersebut terlihat kurang fokus ketika guru memberikan perlakuan. Ketika siswa diberikan perlakuan phonics method, siswa harus benar-benar memusatkan pikiran dan pembunyian kata-kata. Kedua, siswa yang mengalami penurunan kemampuan membaca permulaan pernah tidak masuk ketika pemberian phonics method.

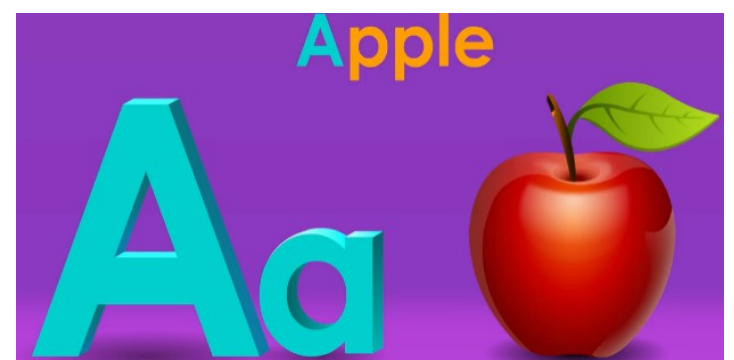

Gambar 8. Huruf Pelafalan dalam Phonics Method

Sehingga, siswa mengalami kebingungan dikarenakan ada beberapa tahapan yang terlewat ketika mereka tidak masuk. Ini menyebabkan siswa tidak sepenuhnya mendapatkan pembelajaran kemampuan permulaan membaca melalui perlakuan phonics method.

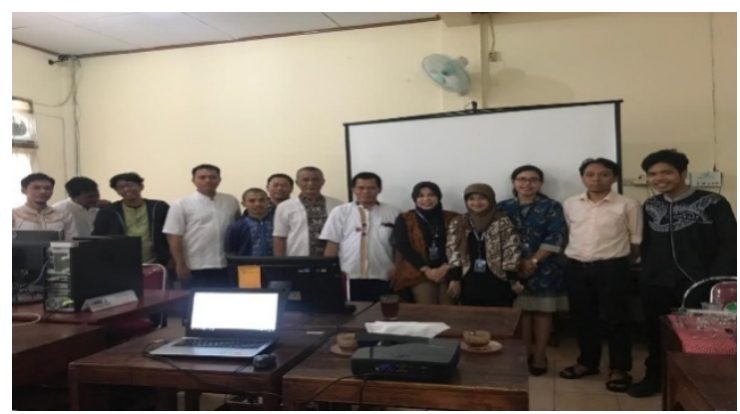

Gambar 9. Dokumentasi saat acara penutupan oleh tim pelaksana dan peserta PKM Guru SMP PATTIMURA Jagakarsa, Jakarta Selatan 
Berdasarkan pembahasan tersebut, dapat ditarik kesimpulan bahwa phonics method berpengaruh terhadap kemampuan membaca permulaan pada siswa, walaupun ada siswa yang mengalami penurunan ketika pelatihan phonic method di SMP PATTIMURA Jagakarsa Jakarta Selatan. Dokumentasi di atas menunjukkan kegiatan penutupan PKM di SMP PATTIMURA Jagakarsa, Jakarta Selatan.

\section{KESIMPULAN}

Berdasarkan hasil pelatihan tentang Phonic Method dapat disimpulkan bahwa pengenalan konsep suara dan pengucapan bagi guru SMP PATTIMURA melalui kegiatan pembelajaran dengan strategi Phonic Method merupakan salah satu alternatif pembelajaran yang baik untuk dilaksanakan. Kegiatan pembelajaran tersebut cukup menarik minat guru untuk ikut berpartisipasi secara aktif dalam kegiatan pembelajaran siswanya nanti. Para guru juga mulai mengenal dan mampu mengidentifikasi perbedaan ejaan bunyi dan huruf, dapat meneruskannya, bahkan mampu melafalkannya sendiri melalui strategi aktivitas phonics method. Pada saat kegiatan membaca melalui phonics method, bahwa kemampuan bercerita anak mengalami peningkatan.

Berdasarkan kesimpulan tersebut di atas, berikut disampaikan beberapa saran yang ditujukan kepada para guru, siswa, dan tim kegiatan pengabdian masyarakat dan Sekolah.

Sekolah diharapkan menyediakan media pembelajaran yang dapat menarik perhatian dan minat siswa untuk belajar lebih giat atau baik lagi. Selain itu sebaiknya metode penyampaian lebih mengutamakan pada kesabaran serta rasa senang hati dengan demikian akan menanamkan rasa senang pada anak dalam proses pembelajaran. Mengacu pada hal tersebut disarankan bagi bahwa bagi Sekolah diharapkan mampu mengarahkan guru untuk menggunakan metode atau strategi pembelajaran yang mempu menarik antusias anak dalam belajar serta menciptakan suasana kelas yang nyaman dan menyenangkan.

Guru lebih meningkatkan kreatifitas dan waktu mengajar dalam pelajaran bahasa Inggris dengan menggunakan media atau permainan yang dapat menarik perhatian siswa, sehingga anak akan mudah mempelajari bahasa Inggris. Selain itu, diharapkan guru bisa mengawasi anak agar memperhatikan guru saat pembelajaran, dan tidak memperhatikan hal-hal lain yang ada disekitarnya sehingga dapat mengurangi perhatiannya dalam pelajaran bahasa Inggris, khususnya pemahaman \& pelafalan kosakata. Bagi guru, ketika pembelajaran berlangsung diharapkan ada dua orang guru atau lebih untuk mengkondisikan serta diharapkan guru berbicara secara tepat dan lantang ketika penmbunyian huruf phonics sehingga anak mampu mendengar dengan jelas.

Sebaiknya para orang tua lebih membiasakan anak mereka untuk sering membaca bagaimana mengeja, mengucapkan \& melafalkan serta hendaknya orang tua ikut memberi bimbingan kepada anak dengan mengulang materi yang telah diberikan di sekolah. Selain itu berikan pujian ketika anak berprestasi baik dan berikan dorongan semangat ketika prestasinya kurang baik.

Dengan telah dicobanya strategi Phonic Method yang cukup komunikatif ini, maka tim pelaksana ABDIMAS menyarankan pada rekan-rekan guru bahasa inggris/non untuk mencoba mencari dan menggunakan strategi pembelajaran lainnya yang dianggap dapat meningkatkan pelafalan kosakata Bahasa Inggris siswa yang merupakan dasar dan tercapainya kompetensi berbahasa. Selain itu, bagi tim kegiatan pengabdian masyarakat lain yang akan melakukan pelatihan dengan metode yang sama, diharapkan lebih jelas lagi dalam tata pelaksanaannya, sehingga mampu melaksanakan pelatihan dengan lebih baik.

\section{DAFTAR PUSTAKA}

Attwell, G. (2007). Personal Learning Environments - the future of eLearning? ELearning Papers, 2(January), 1-8. http://doi.org/10.1080/19415257.2011.643130

Colla, G. (2001). Rainbow Solfege: A Color-Phonic Approach. Teaching Music, 9(2), 32-37.

Cologon, K., Cupples, L., \& Wyver, S. (2011). Effects of targeted reading instruction on phonological awareness and phonic decoding in children with Down syndrome. American Journal on Intellectual and Developmental Disabilities. http://doi.org/10.1352/1944-7558116.2.111 
Connelly, V. (2002). Graphophonemic awareness in adults after instruction in phonic generalisations. Learning and Instruction, 12(6), 627-649. http://doi.org/10.1016/S09594752(01)00034-2

Fridani, L. (2014). Hakikat Perkembangan Bahasa Anak. Metode Pengembangan Bahasa, 1-28.

Gates, L., \& Yale, I. (2011). A Logical Letter-Sound System in Five Phonic Generalizations. The Reading Teacher, 64(5), 330-339. http://doi.org/10.1598/RT.64.5.3

Hendriansyah, D., Milyartini, R., Kurdita, E., Pendidikan, J., Fakultas, S. M., Bahasa, P., \& Seni, D. (2013). PENERAPAN METODE PEMBELAJARAN TUTOR SEBAYA DALAM MENINGKATKAN KETERAMPILAN BERMAIN ORNAMEN SULING LUBANG ENAM (Penelitian Tindakan Kelas di SMP Negeri 4 Subang). Penerapan Metode Tutor Sebaya..., 1(3).

Jung, C. G., Baynes, H. G., \& Beebe, J. (2016). Psychological types. Psychological Types. http://doi.org/10.4324/9781315512334

Lana-Peixoto, M. A., \& Teixeira, A. L. (2002). Simple phonic tic in multiple sclerosis. Multiple Sclerosis, 8(6), 510-511. http://doi.org/10.1191/1352458502ms829oa

Mulyana, T. (2008). Pembelajaran Analitik Sintetik untuk Meningkatkan Kemampuan Berpikir Kritis dan Kreatif Matematik Siswa sekolah Menengah Atas. Educationist, III(1), 43-48.

Mishra, P., \& Koehler, M. J. (2006). Technological pedagogical content knowledge: A framework for teacher knowledge. Teachers College Record. http://doi.org/10.1111/j.14679620.2006.00684.x

Siqueira, V. S. De, Cortez, P. A., Kelly, J., Sobrinho, C., \& Rocha, M. L. (2016). ABECE: An Application for Initial Literacy though the Phonic Method. International Journal of EEducation, e-Business, e-Management and e-Learning, 6(2), 84-90. http://doi.org/10.17706/ijeeee.2016.6.2.84-90

Wyse, D., \& Goswami, U. (2008). Synthetic phonics and the teaching of reading. British Educational Research Journal, 34(6), 691-710. http://doi.org/10.1080/01411920802268912 